\title{
"I might be shot at"! \\ Exploring the Drivers to Work in Hostile Environments using an Intelligent Careers Perspective
}

\author{
Michael Dickmann \\ Cranfield University, School of Management \\ College Road \\ Cranfield MK43 0AL, UK \\ m.dickmann@cranfield.ac.uk \\ Ashley Watson \\ c/o Michael Dickmann \\ Cranfield University, School of Management \\ College Road \\ Cranfield MK43 0AL, UK
}

Corresponding Author: m.dickmann@,cranfield.ac.uk

A submission to the Special Issue of The Journal of Global Mobility on Dangerous Moves and Risky International Assignments 


\title{
"I might be shot at"! \\ Exploring the Drivers to Work in Hostile Environments using an Intelligent Careers Perspective
}

\begin{abstract}
Purpose. This research explores factors which influence individuals to take up international assignments (IAs) in hostile environments. Using an intelligent careers perspective, an expanded framework of expatriation drivers to work in hostile contexts is developed that comprises individual, organizational and location-specific factors. In addition, the understanding of career capital acquisition and transfer is refined.
\end{abstract}

Design/Methodology/Approach. A 'deviant' case study method to challenge the underlying assumptions of career capital maximisation and transfer in global careers is used. To investigate the case, 25 individuals in an international development organisation who had to decide whether to work in hostile environments were interviewed.

Findings. Five insights into decision drivers and career capital effects associated with postings to hostile environments are presented. These span all three levels of individual, organizational and location-specific decision factors.

Research Limitations/Implications. Due to the case study approach the usual limitations of qualitative case based research with respect to generalizability apply. In the conclusions three theoretical implications for the intelligent careers framework with respect to career capital acquisition, utilization and temporal effects are outlined.

Practical Implications. A range of practical implications in relation to the selection, talent management, performance and reward approaches as well as repatriation and family considerations in global mobility are explored.

Social Implications. The insights help organizations to design global mobility policies for hostile environments. In addition individuals and their families benefit from greater clarity of global mobility drivers in the context of high risks.

Originality/Value. The drivers of individuals to accept assignments to hostile environments are under researched. This article operationalizes and applies a holistic decision to work abroad framework, expands the literature on the motivations of individuals to work in hostile environments and develops valuable insights to nuance the intelligent careers framework. 


\section{Keywords:}

Expatriation

Drivers to Work Abroad

Global Careers

Location-specific Expatriation Influences

Intelligent Careers

Hostile Environments 


\section{"I might be shot at"! \\ Exploring the Drivers to Work in Hostile Environments using an Intelligent Careers Perspective}

\section{Introduction}

Individuals who live and work in hostile environments such as Afghanistan, Pakistan, Sudan, Iraq or the Democratic Republic of Congo are likely to shoulder substantial personal risk to their lives, health and families (Bader and Schuster, 2015; Dickmann and Cerdin, 2016). The literature on expatriation motives neglects to build broad frameworks of global work drivers that integrate specific location factors including hostile environments (HEs). This paper sets out the results of research investigating influences which affect decisions individuals make to take up international assignments (IAs) in HEs.

There is enduring interest in global mobility and many commentators argue that many elements of working abroad remain underexplored (Al Ariss and Crowley-Hendry, 2013; Doherty, Richardson and Thorn, 2013; Cerdin and Brewster, 2014). One of these underexplored elements of international assignments is working in hostile environments, the subject of this special issue and another soon to be published (Bader, Schuster and Dickmann, 2019, forthcoming). The world has many dangerous countries and regions (Oh and Oetzel, 2011) but rarely have the broad array of reasons to go onto - or to decline - an assignment been explored in relation to HEs. In fact, the available research is often focussed on advanced developed and secure countries (Froese, Jommersbach and Klautzsch, 2013; Remhof, Gunkel and Schlaegel, 2014; Hippler, 2009). Where there is a focus on the not-for-profit sector, security and risk aspects are not explored in sufficient depth (Oberholster, Clarke, Bendixen and Dastoor, 2013). In addition, while there are a few emerging studies that investigate some aspect of security in the expatriation decision (e.g. de Eccher and Duarte, 2016; Dickmann, Parry and Keshavjee, 2017), it is argued that a broader, more systematic approach to understanding the decision to work in HEs is needed.

Even in secure environments many multinational corporations (MNCs) complain that they find it difficult to fill expatriate vacancies with qualified candidates (The RES Forum 2016). Understanding the drivers of individual expatriation candidates and what organizations could do to sway their decisions in favour of working abroad would be highly beneficial (Cerdin, 2013). Equally, gaining or retaining qualified expatriates in humanitarian organizations can 
be difficult (Dickmann and Cerdin, 2016). In a situation where global careers in not-for-profit organizations are under-researched (Brewster, Boselie, Leisink and Alfes, 2016) understanding the motivations and inhibitions of staff in organizations in the international development sector may be a crucial step to developing suitable expatriation approaches.

The research utilizes an intelligent careers (IC) perspective (DeFillippi and Arthur, 1994) as it is well suited - and often used - to investigate global career moves (Shaffer, Kraimer, Chen and Bolino, 2012; Suutari, Brewster, Mäkelä, Dickmann and Tornikoski, 2017). The IC framework is highly appropriate to explore global career decisions and patterns as it integrates a focus on social capital through an investigation of networks, protean ideas through its exploration of identity and an attention to skills, knowledge and abilities that help to understand the work competencies of individuals (Mäkelä, Björkman and Ehrnrooth, 2009; Parker, Khapova and Arthur, 2009).

Overall, despite some research into the drivers of expatriation decisions, less is known about the career outcomes of IAs in hostile environments. In addition, when deciding to work abroad, many factors beyond IC considerations play a role (Pinto, Cabral-Cardoso and Werther, 2012; Froese et al., 2013, Hippler, 2009). Dickmann (2012) outlines six broad categories of expatriation decision factors. Amongst these are location-specific and national considerations which include security factors. However, almost all research on IC of global careerists has been undertaken in lower risk environments compared to truly HEs such as Afghanistan, Sudan or Iraq. The higher degree of risk has an impact on the freedom of movement of expatriates, their general working environment and interaction as well as what competencies they need to acquire in their host location (Bader, Reade and Froese, 2016; Bader and Schuster, 2015; Dickmann and Cerdin, 2016; Fisher and Hutchings, 2013).

The underlying principles of an IC perspective are that individuals strive to maximize their career capital (Inkson and Arthur, 2001) and that they seek to transfer their acquired new competencies, networks and insights to their next job (Lamb and Sutherland, 2010). In a hostile environment the maximization of career capital and its transfer is likely to be restricted due to security considerations (Dickmann and Cerdin, 2016). Using a deviant case allows to explore the applicability of the IC perspective in high risk situations and may lead to the refinement of theoretical understanding (Emigh, 1997). Using the IC perspective, the 
study investigated what factors influence the decisions of employees to take up international assignments in hostile environments.

The paper first reviews the key literature on the IC framework and on individuals' drivers of assignment decisions to then establish the research question and objectives. How the research was then accomplished is described in the methodology. The paper then goes on to present and discuss the findings. Hitherto neglected expatriation drivers are explored. In the discussion it is investigated how the findings of the study contribute to a more nuanced picture of intelligent careers and expatriation motivations. These insights are used to develop a wide array of practical implications. Finally, the conclusions explore key theoretical contributions and depict limitations.

\section{Literature review}

Individuals working abroad are often described as building intelligent careers (Shaffer et al., 2012; Dickmann and Doherty 2010: 214). IC considerations may influence individual's career decisions as individuals seek to build career capital (Arthur, Claman and DeFillippi, 1995; Parker, Khapova and Arthur 2009). There is extensive literature on career capital and global assignments have been shown to substantially build it (Jokinen, Brewster and Suutari, 2008; Mäkelä, Suutari, Brewster, Dickmann and Tornikoski, 2016). Individuals benefit over long periods of time from expanded career capital (Suutari et al., 2017).

The IC model was originally created by DeFillippi and Arthur (1994) and it seeks to explore individual's career decisions and behaviours. ICs embody three key career capital areas. Knowing how career capital consists of skills, knowledge and ability in relation to successfully mastering current and future work. It includes explicit knowledge, implicit experience, soft skills and technical expertise. Knowing why is the energy, purpose and motivation that individuals bring to the world of work and their jobs. Ideally, this is highly congruent with organizational culture, teambuilding, reward and career management.

Knowing whom career capital is related to the reputation of individuals and how the social connections can help them in their roles. These are embodied in the professional and social networks internal and external to the organization (Inkson and Arthur, 2001). In the last two decades many authors have taken up the concept and have continued to develop the concept and its applications (for a recent contribution see Arthur, Khapova and Richardson, 2017). 
Individuals develop different elements of career capital when working abroad (Suutari et al., 2017; Shaffer et al., 2012). The kind of networks, competencies and insights that individuals acquire through working abroad are context dependent. For instance, a restriction to travel into hostile regions of a country will impact on the career capital that expatriates develop (Dickmann et al., 2017; Bader and Schuster, 2015). In addition, Jokinen (2010) discusses the development of career capital through IAs and states that "each assignment has different developmental influences and that all types of career capital acquired are transferable, but not equally or in the same way".

Thus, how global careerists can maximise their career capital and what is transferable to new roles (Lamb and Sutherland, 2010; Dickmann and Doherty, 2008) may depend substantially not just on the individuals and their work but also on the general context, including the risk profile of their location. There is considerable literature available on building career capital (Shaffer et al., 2012). However, there is little research on how career capital built differs in more HEs. While Dickmann and Cerdin (2016) look at career capital development in a United Nations organization, they concentrate on how individuals acquire career capital through foreign work but do not analyse in-depth the role of it in the decision to accept or reject work in an HE. This gap needs further exploration and research.

\section{Factors having an influence on the decision to accept an IA}

The literature on why people accept IAs has been researched since the 1960s when Cleveland, Magone and Adams (1960) identified the incentives of vocation, financial rewards and escape from uncongenial surroundings as the key influencing factors on expatriation. A few years later, Gonzalez and Neghandi (1967) proposed advancement and recognition, living and travelling abroad, an international career and financial conditions as those incentives which were key for expatriates. In more recent years Stahl, Miller amd Tung (2002) identified the most important reasons for accepting an expatriate assignment as personal challenge, professional development, destination state and importance of the job. Dickmann, Doherty, Mills and Brewster (2008) reviewed individual motivations on why individuals take up posts, the key groupings of considerations that they found to be most important were the position offered, willingness of spouse to move, potential for leadership skills development, career progression and children's educational needs. Over time, the analysis of expatriation and its drivers has become more detailed with some studies exploring specific location factors. For instance, Kim and Froese (2012) investigated host country 
characteristics and occupational role commitments amongst Asian respondents and De Eccher and Duarte (2016) looked at political stability, infrastructure, healthcare, openness of host citizens as well as safety and language.

The extent to which an individual is able to take up an IA influences the decision to accept. Limitation of personal agency may be due to personal factors such as family or work life balance (Harvey, 1985; 1997 - explored below) or level of choice afforded by the organization or direct superiors (Pattie, Benson, Casper and McMahan, 2013). Shaffer et al. (2012: 1290) state that organizations are "hesitant to force candidates to accept" and the effects of declining an expatriation offer can be stark (Bolino, Klotz and Turnley 2017; Pinto et al., 2012). There are examples where the take up of an IA is not voluntary. For example, in Van Emmerik and Euwema's study on Dutch peacekeepers (2009) individuals are assigned to peacekeeping missions and have no choice. The degree of personal agency differs with the individual and the organization, and it has long been suspected that there may be negative implications if individuals turn down an IA offer (Stahl et al. 2002: 220).

While the move towards a more specific understanding of expatriation drivers is welcome, authors rarely attempted to construct a broad framework that allows to generate a more holistic understanding. Notable exceptions include the works by Hippler (2009) and Dickmann (2012). Hippler distinguishes motives that are rooted in the person or personal circumstances, motives rooted in the country and/or location or their features, motives rooted in the new task or position or their features, motives rooted in the candidates' previous position and other motives. Unfortunately, the list did not include security considerations nor were persons interviewed who had rejected an assignment. Dickmann (2012: 795) produced a framework of the "Key Categories of Influence on the International Mobility Decision". These can be distinguished into individual (career and development interests, personal drivers and dispositions, family and partner considerations), organizational (financial rewards and other assignment support) and location considerations (national / regional, specific location context). This framework allows to account for interrelated factors - for instance personal drivers and career considerations - and is able to incorporate security and health considerations which are likely to be highly pertinent for HEs. Below, this framework is adapted and the work distinguishes between individual, organizational and location factors to analyse the literature. 


\section{Individual Factors - Career and Development Interests}

One of the key drivers for international work that has consistently emerged from research is related to the professional interests of assignees, often expressed in relation to the job, development and career elements of their postings (Stahl et al., 2002; Hippler, 2009; Pattie et al., 2013). Modern career writing incorporates all these three aspects. For instance, Arthur, Hall and Lawrence (1989) described a career as an “evolving sequence of a person's work experiences over time". Research to date has found that IAs have evolved to focus more on the individual and their needs rather than on organizational requirements (Sullivan, 1999; Shaffer et al., 2012). This is reflective of growing protean and boundaryless careers (Briscoe and Finkelstein 2009) and the pursuit of individual careers over organizational benefit (Cerdin and Le Pargneux 2009; Altman and Baruch 2012). This means that to incentivise individuals to take up IAs organizations need to understand how they approach their career and how that influences an individual to take up an IA.

In addition to a strong professional driver that is most prominent for assigned expatriates (Doherty, Dickmann and Mills, 2011), the literature on individual influences on the career decision to take up an IA includes personal challenge; efficacy (Stahl et al. 2002; Van Emmerik and Ewema 2009); personal agency (Shaffer et al. 2012: 1290) as well as more personal drivers such as a desire for adventure or travel (Shaffer et al. 2012; Van Emmerik and Euwema 2009; Hippler 2009). These are explored in more detail below.

\section{Individual factors - Personal Drivers and Interests}

Shaffer et al. (2012: 1291) provided some support with their argument that those with an adventuring mind-set are more likely to be interested in IAs. In fact, a sense of adventure, an interest to learn about other cultures and/or specific interests in the history, politics, art etc. of a country or region are all seen as drivers of global work, especially for self-initiated expatriates (Hippler, 2009; Doherty et al., 2011; Cerdin, 2013). This implies that those individuals lower on adventurism or with less developed interests in particular regions or states are less likely to take up an IA.

Seeking international experience, escapism and altruism were key drivers in studies in the not-for-profit sector (Oberholster et al., 2013). While some such as experience and escapism were mirrored in studies from commercial MNCs (Dickmann et al., 2008) and sense-making 
overall is important to expatriates (Pinto and Caldas, 2015), altruism seems to be much stronger in the humanitarian and development aid field (Dickmann and Cerdin, 2016). A range of personal dispositions are important drivers for expatriates. They are described below.

\section{Individual Factors - Personal Dispositions}

Froese et al. (2013) explored how cosmopolitanism works as an antecedent of expatriation willingness. The study of personal dispositions and psychological factors in IAs is well established and is often rooted in the ground-breaking work of Black and his colleagues (Black and Stephens, 1989; Black, Mendenhall and Oddou, 1991). While some have sought to redefine the concept of cultural adjustment (Haslberger, Brewster and Hippler, 2013; Hippler, Brewster and Haslberger, 2015), others have explored the psychological factors that influence the willingness of individuals to work abroad and are linked to their success (Caligiuri, 2000; Downes, Varner and Hemmasi, 2010; Stahl and Caliguri, 2005; Thomas and Inkson, 2009; Remhof et al., 2014). For instance, psychological factors such as extroversion or self-confidence or the ability to be culturally agile are seen as enablers to accept and successfully deliver IA (Caligiuri, 2012; Ott andMichailova, 2016).

The level of self-efficacy defined as the "beliefs that one has in the abilities and resources to succeed at a specific task" (Van Emmerik and Euwema 2009: 140) affects the level of personal challenge an individual is willing to accept. Stahl et al. (2002: 220) found that 82\% of respondents had personal challenge within their top five motivations for accepting an IA. The Van Emmerik and Euwema (2009) study is one of the few that researches international assignments within the not for profit sector in HEs. What influences individuals to take up an IA in an HE on a voluntary basis is neglected in academic research.

\section{Individual Factors - Family and Partner Considerations}

There is significant literature around family and partner influence on individuals taking up IAs. In earlier literature (Gonzalez and Neghandi, 1967 and Cleveland et al., 1960) family and partner considerations were not key motivating factors when taking up an international assignment. In more recent research family considerations have been shown as important (Schoepp and Forstenlechner, 2010; Dupuis, Haines and Saba, 2008; Dickmann et al., 2008). However, this may be related to the national culture of assignment candidates (Kim and 
Froese, 2012). Often, family and partner are viewed as having a negative impact on the likelihood of an individual accepting an IA (Harvey, 1985; Stahl and Cerdin 2004: 893).

Riusala and Suutari (2000) emphasize the importance of children's education for the decision to accept a foreign assignment and other research consistently shows that where expatriates have children in school that the quality of educational provision and the transferability of their qualifications is important to them. In turn, companies tend to be quite generous and are very likely to finance private schools for assignee's children if public provision is perceived to be lacking in quality (The RES Forum, 2016). However, developing offers that are seen as attractive for assignees when faced with the dual careers challenge is far harder. Where partners pursue their own career and who fear negative consequences of moving abroad, assignment candidates have a strong incentive to decline to work in the destination country (Harvey, 1997; Vance and McNulty, 2014). As a result Hippler (2009: 1381) argues that there is increasing immobility of managerial employees and that concerns which come with dual career couples are one factor which may exacerbate immobility.

Where candidates decline expatriation offers (Bolino et al., 2017) and in situations where the level of immobility is high, organizations face a challenge for their global operations. Some of the organizational policies and potential reactions are outlined below.

\section{Organizational factors - Financial Rewards and Non-Financial Support}

Research has established that financial reward is a factor that influences individuals taking up an IA (Gonzalez and Nghandi 1967; Cleveland, Magone and Adams 1960; Hippler 2009; Shaffer et al. 2012). Financial incentives are also attractive to staff in not-for-profit organizations (Oberholster et al., 2013) although their key drives are often linked to a dedication to a cause or internationalization anchors (Dickmann and Cerdin, 2012).

Industry surveys have shown that traditional expatriates have a wide array of further benefits including help for their tax returns, more home leave and paid home transport (The RES Forum, 2016). It is widely suspected that these benefits increase the attractiveness of the expatriation package and that they may influence candidates to accept an international move as well as enable them to keep in touch with the home base (Dowling, Festing and Engle, 
2013; Dickmann and Baruch, 2011). Little is known about the benefits that expatriates in notfor-profit organizations receive and what impact they have on their decision to work in HEs.

Many authors highlight the importance of organizational support practices in relation to predeparture preparation, on-going development and career support as well as repatriation policies (Harris, Brewster and Sparrow, 2003; Dowling et al., 2013). Whatever the length, purpose or format of the IA, the message from the literature is that in order to have a successful IA there must be a high level of support offered by the organization. If organizations are seen to offer good developmental activities for expatriates and do not lose them from their 'radar' during their time abroad we may speculate that this adds to the attractiveness of the IA (Dickmann and Doherty, 2008).

A prominent challenge for organization is repatriation, including career path and job on return (Hurn, 1999; Morley and Heraty 2004). Pattie, White and Tansky (2010: 359) argue that "organizations with more support practices reported a lower than average repatriate turnover compared to organizations with fewer support practices" . The research reflects higher levels of attrition for those returning from IAs (Pattie et al. 2010: 367), albeit this may be only a temporary phenomenon (Doherty and Dickmann, 2012). Overall the consensus in the literature is that organizations do not have sufficient repatriation support in place (Dowling et al., 2013). Talented individuals may be reluctant to take up IAs if they see others negatively affected (Stahl, Chua, Caligiuri, Cerdin and Taniguchi, 2009: 104).

\section{Location Factors - National Considerations}

Most literature on IAs looks at groups of expatriates from secure environments / countries and why they choose to accept IAs (Dickmann et al., 2008; Remhof et al., 2014; Froese et al., 2013). Yurkiewicz and Rosen (1995) found location was a critical factor in accepting an IA and that the reasons behind this may be that the person's language is widely spoken; there is an expatriate community; the country is culturally similar; there is political stability or individuals are attracted by the general climate. These insights gain support through the work of Hippler (2009) and Oberholster et al. (2013). In addition, for engineers language proficiency and cultural attraction was important in their decision to work in emerging economies (de Eccher and Duarte, 2016). For Koreans working in advanced and/or English speaking countries had a higher attractiveness than working elsewhere (Kim and Froese, 2012). 
In essence, countries may be more attractive to individuals if these provide what they are looking for (Haslberger, Brewster and Hippler, 2014). It is argued that a close correspondence of country characteristics with individuals' desires and, therefore, met expectations is conducive to successful expatriation and adjustment (Haslberger and Dickmann, 2016; Haslberger, Brewster and Hippler, 2013). Beyond broad country factors, the literature has only recently started to investigate drivers for individuals to live in specific (city) locations abroad.

\section{Location Factors - Specific Location (City/Rural) Considerations}

Dickmann and Mills (2010) expanded the literature by researching expatriation reasons to work in a specific location, in their case London. Their argument was that it mattered whether finance professionals were to live in London or Leeds in order to further their careers and professional development. In essence, people may be attracted to specific locations within their chosen field of career because they are perceived to be leading edge or especially good for one's career. By extension, the way that locals may treat expatriates or particular security concerns are important when investigating expatriate working in HEs.

Security is not just a country-wide phenomenon. In fact, many hostile states are characterised by regions and cities that are more or less secure, for instance, because of the activities of terrorist networks. Examples would be the North of Nigeria when compared to Lagos or Afghanistan's Helmand province in contrast to Kabul (Murtazashvili, 2016; Giustozzi, 2008). These security concerns are likely to be highly pertinent when individuals consider to work in HEs. While there is extensive IA literature on the motivation to work abroad (Hippler, 2009; Doherty et al., 2011; Pattie et al., 2013) the reasons to work in HEs are relatively underexplored. This led the researchers to strive to identify and explore the main influences on employees' decisions to take up international assignments in hostile environments. Using an IC perspective, this study investigates the following research question:

What factors influence the decisions of non-profit organizations' employees to take up international assignments in hostile environments?

Below the research method is delineated before the findings of the study are presented. 


\section{Research Methodology}

Research on the drivers to accept IAs uses qualitative and quantitative (Hippler, 2009; Doherty et al., 2011) approaches. For the investigation an exploratory, qualitative approach was deemed appropriate due to the lack of earlier studies concerned with HEs and the complexity of the context (Fisher 2010; Birkinshaw, Brannen and Tung, 2011). In essence, the research aimed to gain further insights into the gestalt of decisions to work in hostile environments rather than to test pre-determined relationships. Given the special context of HEs, a 'deviant' case approach was chosen. In deviant cases, the characteristics and outcomes specified by the theory may not occur (Emigh, 1997: 653-655). This indicates limits of generalizability or may result in further theoretical insights or paradigm challenges, in this work with regard to the IC framework (Piekkari, Welch and Paavilainen, 2009).

\section{Procedures of Data Collection}

In 2012 an international development organization in the UK was approached which agreed to participate in the study. The international development organization was a government organization employing 2,653 people throughout the world. $35 \%$ of its employees were working abroad. At the time the organization operated in 27 countries including a number of HEs. It pursued the millennium development goals to alleviate poverty. The organization's vision was to expand in hostile environments. This meant an increase in the number of employees the organization needs to deploy to these locations.

The organization's context in relation to external and internal recruitment for working abroad is regarded as challenging. For the purpose of this paper the locations that are considered are those classified as the highest level hardship IAs. The following locations were seen as most difficult for IAs during the time of the fieldwork: Afghanistan, Pakistan, the Democratic Republic of Congo (DRC) and South Sudan. Within the organization the average IA was 3-4 years. HE IAs are shorter (usually less than 2 years) but the supply of internationally mobile employees did not always fit with the needs of the organization.

Interview Protocol. The interview protocol was informed with enough scope for interviewees to add as required. After an introduction eliciting background and assignment information, the interviews concentrated establishing a baseline of why they had chosen to take up an IA 
or not and why, to investigate the perceived support that individuals gained from their employer and to explore the role of HEs in the decision to work abroad. The interview protocol is in Appendix 1. Within the organization HEs are commonly referred to as 'fragile' environments. Fragile environments are internally defined as areas 'where the government cannot, or will not, deliver core functions to the people, including the poor'. These core functions include security shortcomings and increase the risk of living in these states both for nationals and expatriates. This paper utilizes the descriptor 'hostile' as this is more common in the literature (Dickmann et al., 2017; other articles in that special issue).

The interview protocol was then piloted with 3 interviews. The key change resulting from the pilot was that the protocol was amended to make it clear when slightly differing questions were to be asked of employees currently working in a HE, who had done so previously, and those not willing to work in these locations. On the basis of the pilot, the interview protocol was amended to that in Appendix 1. The pilot interviews were not used for the study.

Interviews. After the design, pilot, and update of the interview protocol, 25 employees were interviewed who were working, willing to work, or not willing to work in HEs. Interviews were conducted face to face, by telephone or by video conference and were recorded and transcribed. They lasted between 30 and 70 minutes and were conducted from June to September 2012. Of the 25 interviewees ten were willing to take up a post in a HE, nine persons were unwilling and six were currently in a hostile environment. The overview of those interviewed is in Table 1.

\section{Research Participants and Sampling Criteria}

A non-random sampling approach was used. Within the organization data on employees who currently work - or have worked in HEs in the 2 years prior to the study - was collated. Management and senior specialist roles were targeted as this was the level the organization had a shortage of individuals willing to take up IAs. In cooperation with human resource specialists in the organization, amongst all the employees staff were approached from specialist and generalist groups that have in the past taken up, are now on, were willing or unwilling to take up IAs in HEs. 28 employees volunteered before 1 September 2012 and were all interviewed (pilot and main study).

\section{Data Analysis}


Data Hierarchy. On the basis of the predesign information and the pilot, an analytical hierarchy was designed. The hierarchy followed Dickmann's (2012: 795) framework for analysing categories of drivers for people taking up IAs. The categories were split into the three levels and distinguished individual decision factors - personal drivers and dispositions, family and partner -, organizational drivers- financial rewards and expatriation support as well as local considerations - national, city and rural - that influence the decision to accept a posting to a hostile environment. This framework enabled analysis of the data within the same framework as the literature. The full data hierarchy is outlined in Table 2.

Analysis. Once interviews were transcribed the analysis was conducted as follows. The individual transcripts and the CVs of the individuals interviewed were uploaded to NVivo. Then, using the hierarchy available in Table 2 each interview transcript and CV was coded into the hierarchy. In the next step, a personal classification was entered into NVivo which detailed all demographic information. Reports were then run on each element of the hierarchy. The data was discussed amongst the two authors and, at times, coding and meanings were clarified.

\section{Findings - Factors leading to the Acceptance of IAs}

In the organization, some professionals regard working in hostile environments as a rite of passage.

“Well you have to do a fragile state - I wanted to get it out of the way." (Interviewee 21)

It seems to be that there are some highly international organizations - for instance in the international humanitarian field - where working abroad is intimately connected to the mission or core interests of the entity (Dickmann and Cerdin, 2016; Pinto and Caldas, 2015). Refusing to accept an international assignment may seriously harm an individual's chances of internal progression (Pinto et al., 2012; Bolino et al., 2017) and there was a strong expectation in the case organization to work abroad in order to pursue its humanitarian mission.

The paper now details the findings from the interviews exploring the drivers of global careerists and will discuss these in the following section using the Dickmann (2012) 
categorization which have been segmented into individual, organizational and location factors.

\section{Individual Factors - Career, Development and Personal Interests, Individual Disposition and Family Considerations}

\section{Individual Factors - Career and Development Interests}

Interviewees indicated one influence in taking up IAs in HEs was because they felt it would benefit their careers. There was evidence that individuals took up assignments within a conflict or hostile state to gain promotion. Of 19 interviewees who had worked in HEs seven had one or more promotions directly related to their IA in a HE. For those who had been in the organization longer and taken up a hostile environment IA, promotion was part of the reason they took up the post:

"I am not hugely ambitious regarding promotion but I at least wanted to get to the next level. One of the things about getting to Afghanistan was with the challenge of the role out there and the exposure that would give me for promotion."

(Interviewee 14)

There were many positive stories of promotion and internal data showed that expatriates from HEs were more likely to be promoted than staff in non-hostile environments.

\section{Individual Factors - Professional Interests in Career Capital Development}

Employees who had worked in these locations felt they had learned a significant amount. Below, the IC framework is used to structure the findings into knowing how, knowing whom and knowing why.

Knowing How: Beyond the employing development agency into government. Learning was around leadership, prioritisation, self-awareness, flexibility, adaptability and resilience, working across government, and working in an international and multicultural environment.

I have learned lots about the people, the culture, a little bit of the language, the history.... How [we] and other donors approach certain problems and how the international aid system works in a place like this." (Interviewee 16) 
Individuals felt that they had to learn much more quickly and intensively than they would have done in a non-hostile environment. Interestingly, 4 out of 5 interviewees who had previously worked in Helmand province in Afghanistan reflected that the skills and experience they had built included elements of: leadership, resilience and self-awareness. In terms of transferability they had an unusual impression. According to these interviewees, the mentioned skills were recognised more across government and not acknowledged as much by the organization. Two expressed a view that this was because, when working in these locations this work was:

“..on the edge of [our work] and at the centre of government” (Interviewee 13)

Overall, a large majority of assignees argued that working abroad contributed to knowing how capital maximisation. In terms of knowing how transferability, however, it seemed that the building of career capital was not seen as an incentive or positive influence to encourage individuals to take roles in hostile environment for a career within the organization but rather in the wider government. Thus, there is a tension between the career paths expected as a government employee and as a development professional. This tension has been hitherto not sufficiently explored.

Knowing Whom: The 'far away, in sight, into the mind' phenomenon. The perception of interviewees was that they could built their HE networks (e.g. in Helmand, Iraq, South Sudan) rapidly (knowing whom maximisation) and that these were more helpful across government or in their host country than within their employing organization. An interviewee commented:

"...so at the time you get disproportionate access to very high reaches of government both in your own government and everyone else's as well." (Interviewee 13)

These individuals also expressed that they felt their time in a HE had been beneficial to their career beyond the organization due to their increased social capital in government. As with knowing how capital, knowing whom capital could be maximised but the transfer was seen as more beneficial to government rather than to their own organization. 
Knowing Why: Insights that HE assignees may have to leave the organization to use knowing how. There was an acknowledgement that knowing why capital was built on HE IAs. For example one employee stated that:

\section{"I like fragile states - they are more interesting" (Interviewee 21)}

For those who had not been in HEs the perception was that in countries where movement is more restricted and the individuals role may face inwards to the organization or to the UK government. Those individuals may choose not to go to a particular country due an interest in building career capital in development and local government rather than the UK government.

Those who had worked in Afghanistan, Iraq and other HEs were confident that both types of knowing why career capital were built in these countries. However, they faced a conundrum. To have their increased career capital recognised many thought they had to leave the organization. The reason was that the knowing why capital built sometimes related to how the UK government operated and not the particular country.

\section{Individual Factors - Personal drivers and interests}

Overall for most interviewees, the link of personal interests and job characteristics in HEs was the first thing that influenced them when thinking about taking up a post. Interviewees currently based or who had previously had IAs in this location, thought this was the way people should think about taking up posts in these locations. The majority of interviewees had positive perceptions of roles in HEs.

"It is one of the least developed countries in the world - there are access issues and insecurity, the transition between humanitarian and development responses - it is a fascinating context to work in." (Interviewee 21)

The main positives regarding the challenge of the role were that employees felt the roles and context were interesting and they could have a big and recognisable impact. The challenge of the role was the main reason they would be influenced to work in HEs for 16 out of 25 interviewees. 


\section{Individual-Personal Dispositions}

In relation to personal efficacy three individuals mentioned that when they applied for a role they needed to be confident that they were capable of performing the role. One of these interviewees had previous experience of working in HEs and she applied partly because she was confident of her personal efficacy. The other two did not apply as they were not confident that they would be able to raise to the multitude of challenges facing those who work in hostile environments.

In line with other research (Dickmann and Cerdin, 2016; Takeuchi, 2010) it was clear to expatriation candidates and assignees that working abroad - particularly in an HE - would result in stress and mental challenges.

....like the level of awareness of the kinds of cumulative stress as much as PTSD which is triggered by single events" (Interviewee 13)

Interviewees in the organization outlined as an additional challenge that working in HEs would likely result in the added issue of mental health and the necessity of coping with traumatic events - for which they saw little organizational support.

\section{Individual Factors - Family and Partner Considerations}

In parallel to the existing literature, a key influencing factor for the decision to work in a HE was whether the individual had a partner, family and children.

Partner's Dual Career. Of the 25 people interviewed 18 were married, in a civil partnership or a relationship, six were single, and one divorced. From 18 with partners or spouses 13 were currently working. They all considered their partner when deciding to take up an IA.

Certain spheres of work, for example consultancy, academia and international development meant that partners were able to follow their partners and take an alternating view of optimizing their careers. An employee whose partner is a specialist in international development in a conflict context stated: 
"His turn, my turn, his turn, my turn .... Often one of us would get a job, we'd all go, and then the other one would get a job when we got there .... On two occasions we both got jobs before we left ... that is very rare and a very, very great thing." (Interviewee 11)

The 6 weeks on, 2 weeks off working pattern for some HEs makes it easier for partners if they wished to stay at home so that they could build their career. The partner was a critical influencing factor in enabling the individual to take up an IA by the support and compromise they provided.

Family and Children's Education. For 'unaccompanied' posts if individuals were dependent on their spouse or partner to look after children or have to arrange full time care e.g. boarding school or an au-pair, this had a large influence on the decision to take up an IA. One interviewee indicated that his wife had been under significant amounts of pressure looking after children alone, at home when he went on an 'unaccompanied' post:

"It is stressful for your family as well. My wife was coping with all sorts of things on the family front on her own. I wasn't there. My son who was 9 or 10 when I went away became distraught and quite troublesome for a while and she had to deal with that. I remember having to chastise my kids over Skype which is just not good." (Interviewee 14)

For all HE IAs, education was an important influence in individuals deciding if they wish to take up IA and, if they do, how they manage their families when doing so. The older the children, the more critical this was to their parents, and the higher the concern on the quality of education.

In extrema, individuals made the decision to stop accepting IAs, as they felt that the best place for their children to be educated was in the UK (3 individuals). For the individuals who had children this meant that those who had a partner, who could look after children at home in the UK, were more likely to take up an IA in a HE. For those who were single parents, or who did not have a partner who could take on the caring role this was a barrier to taking up HE IAs.

\section{Organizational Factors - Financial Rewards and Non-Financial Support}




\section{Organizational Factors - Financial Package}

There were very different views on the financial allowances within the research. Views of interviewees were split depending on the location of the IA, nationality and if that person had a family at home. Most interviewees felt that allowances are not the motivating factor for them to take up an IA and organizations should not make them too high as this may incentivize people to go to hostile locations who were motivated only by the money:

"I never looked at the allowances until I had a long chat with [Name], and I was confident that I could bring some skills to the job. I did not even look at the money until I had pretty much made up my mind that I was going to apply for the job. I think that is the right way round to do it" (Interviewee 25)

In the research the individuals who thought the financial package was most important were six women and a man. For the three women under 40 their motivation for financial benefit was to pay off student loans ( 1 interviewee) and to save up a deposit for a house ( 2 interviewees). For the other four individuals the additional money was important as it facilitated payment of school fees and benefited their families.

\section{Organizational Factors - Assignment Benefits including Leave Provisions}

Critical influencing factors when deciding whether to take up an international assignment (IA) were leave, flexibility and length of IA. For unaccompanied IAs, interviewees with experience of HEs saw the rota and recuperation leave as vital for their health, well-being and for being able to maintain their family life and personal networks. This leave had a high influence in decision making to take up the IA. Combined with the shorter length of the assignment, these arrangements attract employees who wanted to minimize disruption to their family or partner but liked to take up an IA:

"Afghanistan was a compromise, let's be clear on that. But it does enable a bit of the best of both worlds. We could live as a family in London; I could work overseas in a country programme. If it was not a 6 and 2 rotation I would not have had a strong reason to do it"

(Interviewee 22)

Six interviewees stated that the shorter the minimum length of IA, the more easily they would commit to it. Other interviewees also stated that arrangements such as job-share would 
increase their ability to take up IAs. In contrast, two specialists stated that they would have concerns taking up an IA of less than two years as they felt that they would not be in that location for sufficient time to have an in depth understanding of the country and perform the role well.

\section{Organizational Factors - Support during and after assignment}

During the assignment employees found that if they had a good line manager this provided the majority of support that they required, and some were provided with coaches or mentors during assignment. This support was seen as critical if they were to consider going to a HE:

"It is not about the money and is much more about the support in terms of logistics, accommodation and support in pastoral care and technical backstopping. If they got that right then I might well consider it. At the moment the personal cost is too great and I am not willing to do it until I think they are actually willing to look after people better." (Interviewee

The provision of mentoring on an IA both assists the employee to succeed in country but also connected them to the wider organization. Interviewees indicated that this then has an impact on their success in their current role, and their willingness to take up a future IA.

In the organization there was some redeployment support, but no compulsory debriefing set up on return from any country. At the time of data collection four people took up psychological re-integration support. Eleven assignees, out of 15 people who had previously done a HE assignment, thought that the organization could do more to support individuals during and on return from HEs. One of the key concerns from individuals was that the organization did not provide any way for line managers who may be managing returnees or individuals to educate themselves on the effect of taking up an assignment in a difficult location. This meant that individuals who had been to an HE IA and felt they had a negative experience, may on returning, influence others who may then be apprehensive about taking up a similar IA.

\section{Location Factors - National and Location-Specific Factors}

\section{Location Factors - National Considerations.}


Interviewees gave examples of being interested in the language, region, culture and politics which is in tune with other research (Hippler, 2009; Oberholster et al., 2013). The profile and reputation of the local office was also important and was seen to represent the work in the country (and the political attention it would generate from London) rather than the specific city it was located in. Those posts that were high profile and therefore attracted ministerial and press attention were more popular locations as this exposure was seen to be good for individuals' careers. The reputation of the particular country office location was important to individuals, including the quality of work, the management and what it was like to live and work there. Three interviewees expressed thoughts like:

"When I think about a role I want responsibility, opportunity, a really interesting job with a really good head of office. I don't think that you can underestimate how important they are, the personalities. That can make the difference on whether it is an incredibly successful IA or a real challenge" (Interviewee 25)

One of the main reasons for interviewees to decline the IA ' was if they did not have sufficient trust in the line manager or the head of office. This was because in an HE when you live and work with an individual who is taking decisions that can literally affect one's chances of survival you need to trust that person. This particular insight has so far been underexplored in extant research on the willingness to work abroad (Hippler, 2009; Doherty and Dickmann, 2012).

The national location issue that concerned individuals was the status the organization gave to the post, whether it could be accompanied, unaccompanied or it had some family restrictions. This was mentioned by all respondents as a key influence. More specific location issues related to security and freedom of movement and interaction in relation to where individuals lived and worked.

\section{Location Factors -Specific City or Region within Country}

Crucially, security and freedom were intrinsically interlinked when working in a HE. The level of security, and limitations to freedom were important when individuals considered taking up an IA. This varied with location and was specific to cities or areas. The level of security influenced the interviewee's decision on where to go for two main reasons. One group did not wish to go anywhere where they were in substantial personal danger: 
The others were concerned about the restrictions on freedom. They felt limited in three ways. They felt they did not have sufficient freedom to get out to see the work on the ground; were subsequently hindered to develop strong relationships with those they work with in remote areas; and, consequently, found it difficult to develop their skills. Thus, the risks associated with specific locations would be a barrier to career capital maximisation. In addition, at times, individuals felt that security levels were too high which would result in the three detrimental effects outlined above.

Specific locations make a difference for security and freedom reasons and because of the implications this has for the work that can be done. Security considerations were most important in conflict zones. Individuals mentioned their concerns when located in specific regions of DR of Congo and Cambodia as there were on-going conflicts there. In contrast, the capital cities were not a conflict zone and represented a different expatriation proposal. One example was working in Helmand province which had a high element of working with the military and higher security issues, as opposed to Kabul which was focused more on cross government work and embodied a lower security threat. In Nigeria working in Kano rather than Abuja meant that there were higher levels of freedom and more grass roots development work.

The findings of the field work showed a number of highly interesting developments with respect to the decision to accept or reject working in a hostile environment. These are discussed below.

\section{Discussion}

The driver of this work lies in the attempt to refine the IC framework in the context of the relative dearth of information on why global careerists accept (or reject) a posting to a hostile environment. Existing broad frameworks by Dickmann (2012) and Hippler (2009) concentrate on a for profit context. Even where research exists that looks at not for profit organizations (Oberholster et al. 2013) it - like the for profit frameworks - inadequately distinguish between moves to developed, secure countries and hostile, conflict-ridden environments. 
The findings show a large array of reasons that either motivate or hinder individuals in one international development organization to accept IAs to the highly risky HEs of South Sudan, DR of Congo, Afghanistan and Pakistan. Building on the literature a large number of individual, organizational and location factors have been suggested that have an impact on individuals' decision to accept a hardship location posting. Overall, Table 3 shows that all suggestions within these categories from the literature looking at 'safe', normally highly developed locations were supported for moves to HEs. Given the dearth of information on HEs, it would be important to build on the applicability of the items from the literature in order to assess the relative importance of these drivers.

\section{Insert Table 3 here}

While the data confirms the key tenets of the existing literature, it expands insights in all three categories with HE-specific considerations. The differential impact on individual, organizational and location considerations on reasons to accept or reject assignments is further explored below:

Individual Career and Development Factors - Different career capital acquisition patterns in HEs. For individual factors this research nuanced the understanding of the role of career capital. The research supported that knowing why, knowing whom and knowing how career capital was built and transferred (Jokinen, 2010; Dickmann et al., 2016). However, the interviews indicated that the career capital acquisition patterns were different to working in a non-hostile environment. Interviewees indicated that they had to gain new insights more quickly due to the high levels of risks and what was at stake. The practical implications for global talent management are substantial. In addition, the speed of learning, network building and personal insights has not been subject to IC theory-building nor has it been exhaustively researched.

Individual Career and Development Factors - Different career capital utilization patterns in HEs. Interviewees felt they built career capital through working abroad which has also been shown in other research (Jokinen, Brewster and Suutari, 2008). Interestingly, and in contrast to some other humanitarian research (Dickmann and Cerdin, 2016) in this case organization interviewees argued that their career capital acquisition allowed them a faster promotion than 
in any other role outside a HE due to the pace and pressure of their roles. However, career progression may entail the move beyond this organization to government in order to transfer their acquired career capital. Thus, the utilization and transfer patterns of career capital were geared to wider government roles rather than to within their organization.

Most IC research amongst global careerists explores transfer patterns within the employing organization (Dickmann and Doherty, 2008; Shaffer et al., 2012; Doherty and Dickmann, 2012). In the present research the career capital on knowing why was not simply related to the current employing entity or other industry organizations, it was seen as motivating for work related to either the host country or across wider government. For knowing whom capital all of those who had worked in a HE had strong personal networks. For knowing how individuals felt that they had acquired competencies that were more transferable to wider government roles rather than within their organization. In other words this study indicated that some individuals felt career capital built in highly militarised or secure locations was more suited to working across government and that career capital built in the less restricted but still HEs was more suited to working in development. With respect to practical implications, these insights can be used to inform career and succession planning as well as performance management. The current work might be used as a basis for further expatriation research to distinguish individuals' career path decisions and perceived marketability (Suutari et al., 2017).

Individual Dispositions - Mental Health Considerations are important for HE assignments. While the literature has begun to call for a stronger focus on well-being and mental health issues of people working abroad (Burkholder, Joines, Cunningham-Hill, and Xu 2010; Jones, 2000), this concentration has only recently started to emerge (e.g. Bader and Berg, 2013; Takeuchi, 2010). The interviewees discussed traumatic events and coping issues which are more likely to occur in hostile environments. It can be seen from the work of Bader and Berg (2013), Takeuchi (2010), Street, Gradus, Hannah, Giasson, Vogt and Resick (2013) as well as Van Emmerik and Euwema (2009) that there are many stresses and traumas that expatriates in HEs can be exposed to - especially in those environments that suffer from high conflict and terrorist incidents. While these authors present insights into the mental health challenges, organizations would be well advised to factor stress, general health and well-being considerations into the selection, on-going management, crisis reaction and repatriation plans 
of their expatriates in hostile contexts. In addition, these issues should also be included in frameworks and research exploring the influencing factors and reasons to go to work abroad.

Organizational Factors - Travel and Leave Arrangements are a key considerations to accept work in HEs. In terms of organizational inducements, it is clear from the literature that both pay as well as other benefits are important to individuals in their decision to accept an assignment (Hippler, 2009; Stahl et al., 2002). In general, it seems that pay is relatively important (Dickmann et al., 2008) in comparison to travel and holiday/leave arrangements in for profit MNCs. The interviewees, however, attributed a high importance to holiday and leave arrangements as they saw them as important for their family contact and social activities. It might be that in HEs - given their restriction to personal freedoms such as the ability to move about freely or the specification of host locations as non-family - the importance of these benefits are particularly high to expatriates and candidates alike. In terms of management implications this means that IA experts may consider trade-offs between actual pay and added travel and holiday times and may also make sure that the job demands allow expatriates to take advantage of these, maybe even to work part of their time from secure locations near their families.

Specific Location Factors - Security and Trust Issues are key components in the decision to work in HEs. As can be expected, security in HEs is a paramount consideration for candidates to work abroad. There is some research on coping mechanisms of (female) military personnel (Fisher, Hutchings and Pinto, 2015) and other challenges of military personnel in high risk environments (Crowley-Henry and Heaslip, 2014). In addition, there are some studies looking at country images and security, albeit not covering specific locations (de Eccher and Duarte, 2016). Specific locations - e.g. the capital city versus insecure, rural regions - within a country and even specific line managers and colleagues to work with were really important for expatriation candidates. Some interviewees did not want to work with particular line managers as this might reduce their chances of a good outcome in 'sticky' situations in hostile contexts. It shows how important it is to understand the specific local context and to explore specific security and trust considerations when researching - or managing - reasons to go on an assignment in HEs. With respect to management implications, organizations would be well advised to engage all leaders, expatriates and staff in HEs in security training and crisis scenario handling. As a by-product, they may alleviate withdrawal cognitions of expatriates in HEs (Bader, Reade and Froese 2016). 
Unfortunately, the IC framework does not sufficiently incorporate factors such as trust and the competence of line managers which according to the interviews have an impact on location choice, acceptance and networking behaviours. In situations where people might be shot at this seems to be highly important. The resulting theoretical implications of the study are discussed below.

\section{Conclusions}

A qualitative, exploratory study into what influences individuals to take up an IA in a HE was conducted. One strengths of this study is that a more holistic framework of location choices than has hitherto been used in the global mobility literature was developed. In addition, the discussion section has outlined five empirical contributions through which the existing insights from the expatriation willingness and location choice literature are expanded and a wide array of management implications are outlined.

This was a small, qualitative study in a non-profit organization so that the usual limitations of exploratory research apply. All the expatriates in the study were assigned expatriates and this means that for HEs other types of expatriates' views are not reflected in this exploratory study. All the interviewees were at the same grade band within the organization. The interviews were carried out by one person, who was a member of that organization; this may result in bias if the individuals felt they could not be open and honest or projected a particular view to influence the interviewer. On the other hand, the fact that the researcher was part of the organization may have also aided the openness of interviewees and created a superior understanding. Nevertheless, given the nuanced insights on the details of decision factors why individuals may accept work in a HEs the data appears useful and extensive. At any rate, these limitations must be taken into account- many which generally apply to small scale qualitative research - when considering the three key theoretical implications that arise from the research.

\section{Theoretical Contributions}

First, with respect to the individual level different career capital acquisition patterns in HEs were found. Assignees actually acquired career capital more quickly in a hostile context as it was of utmost importance, potentially a condition to stay alive. The high degree of risk nuanced insights with respect to knowing how and knowing whom career capital (DeFillippi 
and Arthur, 1994). The IC framework hitherto does not specify time and speed of career capital acquisition. Incorporating a time element could refine the understanding of career capital acquisition and modern global careers.

Second, extant IC research is predominantly interested in transferability per se (Lamb and Sutherland, 2010; Dickmann and Baruch, 2011) rather than whether individuals can utilize their acquired career capital within their own organization or in other entities. The data showed that the career capital acquisition in HEs can be more suited to move organizations to work with the wider government as expatriates gained valuable social connections and competencies from operating in hostile environments. Moreover, actual academic research into retention patterns post assignment (Doherty and Dickmann, 2012) is concerned about the high level of repatriate turnover. Thus, one recommendation is that the IC framework takes more explicit account of where the acquired career capital can be utilized and what practical implications this has for organizational global mobility policies and practices in the areas of staffing, performance management, career and repatriation planning.

Third and with respect to location-specific factors, security considerations are extremely important to expatriation candidates and expatriates alike (de Eccher and Duarte, 2016). While this is related to the external environment in the specific location - rather than the country research that is prevalent in the literature - the interviewees gave interesting insights into their internal considerations in relation to security. Due to the heightened chance of dangerous situations they would evaluate management in the host location closely bearing in mind their assessment of whether local leaders would do the right thing to manage risks. This trust element should be incorporated in future research. Overall, the quality, content and mechanics of the key relationship of the (potential) expatriate to his or her line manager in HEs is underspecified in the IC framework (Inkson and Arthur, 2001; Arthur et al., 2017) and deserves further exploration.

\section{Practical Contributions.}

The five key findings presented above allow to draw up a wealth of practical recommendations. In the discussion section a large array of practical implications was outlined. On the individual level, understanding the way that hostile environments lead to substantial and rapid changes in career capital could allow staff to explore their own ICs in more depth, become more protean and proactive in their career planning and behaviour. It 
would allow them to more proactively shape their careers, especially if they find common goals and win-win approaches to the challenges of working abroad in the context of high risk environments (Pattie et al., 2013). Organizations, in turn, would benefit from refining their global mobility attraction, management, reward, development, career and retention approaches bearing in mind the different intelligent career implications of working in hostile environments. While it is obviously difficult for an organization or individual to eliminate the risks that the hostile environments they are embedded in pose, the planning, security training and crisis reaction capabilities of actors need to take adequate account of the volatile, uncertain, complex and ambiguous environment that they face.

This study has considered one organization within international development which is expanding its activities in HEs. It is argued that it is important for this humanitarian agency to understand the driver of its staff and how to manage its assignment package, support mechanisms and crisis preparations. It is in these locations that some of the highest levels of poverty and inequality exist. The case study organization and other actors in the international development sector, such as the World Bank and the United Nations can have a key role in meeting the goals of developing crisis-ridden states and to alleviate poverty. To achieve this there was the requirement to increasingly deploy individuals on IAs. Therefore, it is also important to refine the insights into modern global careers and expatriation drivers. Lastly, it is vital that these insights are used by employers to address key factors that affect expatriation decisions and encourage individuals to take up IAs in HEs.

Note: The views expressed in this paper by interviewees or authors belong to them and not the organisations they work for.

\section{References}

Al Ariss, A. and Crowley-Henry, M. (2013), "Self-initiated expatriation and migration in the management literature: present theorizations and future research directions", Career Development International, Vol.18 No. 1, pp. 78-96.

Altman, Y. and Baruch, Y. (2012), "Global self-initiated corporate expatriate careers: a new era in international assignments?" Personnel Review, Vol. 41 No. 2, p. 233-355.

Arthur, M., Hall, D. and Lawrence, B. (1989), Handbook of Career Theory. Edited Book, Cambridge University Press, Cambridge. 
Arthur, M., Claman, P. and DeFillippi, R. (1995), "Intelligent enterprise, intelligent career", Academy of Management Executive, Vol. 9 No. 4, pp. 7-20.

Arthur, M., Khapova, S. and Richardson, J. (2017), An Intelligent Career: Taking Ownership of Your Work and Your Life, Oxford University Press, Oxford.

Bader, A.K., Reade, C. and Froese, F.J. (2016), "Terrorism and expatriate withdrawal cognitions: the differential role of perceived work and non-work constraints", The International Journal of Human Resource Management, pp. 1-25. doi: 10.1080/09585192.2016.1233448.

Bader, B. and Berg, N. (2013), "An empirical investigation of terrorism-induced stress on expatriate attitudes and performance”, Journal of International Management, Vol. 19 No. 2, pp. 163-175.

Bader, B. and Schuster, T. (2015), "Expatriate social networks in terrorism-endangered countries: An empirical analysis in Afghanistan, India, Pakistan, and Saudi Arabia", Journal of International Management, Vol. 21 No. 1, pp. 63-77.

Bader, B. Schuster, T. and Dickmann, M. (2019), "Special issue of The International Journal of Human Resource Management: Danger and risk as challenges for HRM: how to manage people in hostile environments", The International Journal of Human Resource Management, forthcoming.

Birkinshaw, J., Brannen, M. Y. and Tung, R. (2011), "From a distance and generalizable to up close and grounded: Reclaiming a place for qualitative methods in international business research”, Journal of International Business Studies, Vol. 42 No. 5, pp. 573-581.

Black, J.S., Mendenhall, M. and Oddou, G. (1991), "Toward a comprehensive model of international adjustment: An integration of multiple theoretical perspectives", Academy of Management Review, Vol. 16 No. 2, pp. 291-317.

Black, J.S. and Stephens, G.K. (1989), "The influence of the spouse on American expatriate adjustment and intent to stay in Pacific Rim overseas assignments", Journal of Management, Vol. 15 No. 4, pp. 529-544.

Bolino, M.C., Klotz, A.C. and Turnley, W.H. (2017), "The implications of turning down an international assignment: a psychological contracts perspective", The International Journal of Human Resource Management, Vol. 28 No. 13, pp. 1816-1841.

Brewster, C., Boselie, P., Leisink, P. and Alfes, K. (2016), "Beyond the private sector: International HRM in the not for profit sectors", In Dickmann, M., Brewster, C. and Sparrow, P., International Human Resource Management: Contemporary HR Issues in Europe, pp. 145-168. Routledge: London.

Briscoe, J.P. and Finkelstein, L.M. (2009), "The "new career" and organizational commitment: do boundaryless and protean attitudes make a difference?" Career Development International, Vol. 14 No. 3, pp. 242-260. 
Burkholder, J.D., Joines, R., Cunningham-Hill, M. and Xu, B. (2010), "Health and well-being factors associated with international business travel", Journal of Travel Medicine, Vol. 17 No. 5, pp. 329-333.

Caligiuri, P.M. (2000), "The big five personality characteristics as predictors of expatriate's desire to terminate the assignment and supervisor-rated performance", Personnel Psychology, Vol. 53 No. 1, pp. 67-88.

Caligiuri, P.M. (2012), Cultural Agility: Building a Pipeline of Successful Global Professionals. Jossey-Bass, San Francisco.

Cerdin, J.L. (2013). Motivation of self-initiated expatriates, "Self-initiated expatriation. Individual, organizational, and national perspectives," pp.59-74. in Andresen, M., Al Ariss. A., and Walther, M. Self-initiated Expatriation: Individual, Organizational and National Perspectives, London, Routledge.

Cerdin, J.L. and Brewster, C. (2014), "Talent management and expatriation: bridging two streams of research and practice", Journal of World Business, Vol. 49 No. 2, pp. 245-252.

Cerdin, J.L. and Le Pargneux, M. (2009), "Career and international assignment fit: toward an integrative model of success", Human Resource Management, Vol. 48 No. 1, pp. 5-25.

Cleveland, H., Mangone, G. and Adams, J. (1960), The Overseas Americans. McGraw-Hill, New York, NY.

Crowley-Henry, M. and Heaslip, G. (2014), "Short-term international assignments. Military perspectives and implications for international human resource management", European Management Journal, Vol. 32 No. 5, pp. 752-760.

De Eccher, U. and Duarte, H. (2016), "How images about emerging economies influence the willingness to accept expatriate assignments", The International Journal of Human Resource Management, 1-27, http://dx.doi.org/10.1080/09585192.2016.1172653.

De Fillippi, R. and Arthur, M. (1994), "The boundaryless career: a competency-based perspective", Journal of Organizational Behavior, Vol. 15 No. 3, pp. 307-324.

Dickmann, M. (2012), "Why do they come to London? Exploring the motivations of expatriates to work in the British capital", The Journal of Management Development, Vol. 31 No. 8, pp. 783-800.

Dickmann, M. and Baruch, Y. (2011), Global Careers, Routledge, London.

Dickmann, M. and Cerdin, J.-L. (2016), Exploring the Development and Transfer of Career Capital in an International Governmental Organization, The International Journal of Human Resource Management, Vol 27 No 1, pp. 1 - 31.

Dickmann, M. and Cerdin, J.-L. (2012), "Hardship careers in the UN: What drives humanitarian workers on?" Sponsored Showcase Symposium led by S. Khapova, S. and M. Arthur, Consequences of employees" "giving behaviour" at work, Annual Meeting of the Academy of Management, August 3-7, in Boston, Massachusetts, USA. 
Dickmann, M. and Doherty, D. (2010), "Exploring organisational and individual career goals, interactions and outcomes of developmental international assignments", The Thunderbird International Business Review, Vol. 52 No. 4, pp. 313-324.

Dickmann, M. and Doherty, N. (2008). "Exploring the Career Capital Impact of International Assignments within Distinct Organisational Contexts", British Journal of Management. Vol 19, No. 1, pp. $145-161$.

Dickmann, M., Doherty, D., Mills, T.I. and Brewster, C. (2008), "Why do they go? Individual and corporate perspectives on the factors influencing the decision to accept an international assignment", The International Journal of Human Resource Management, Vol. 19 No. 4, pp. 731-751.

Dickmann, M., Parry, E. and Keshavjee, N. (2017), "Overcoming structural career barriers an exploratory investigation into localization of staff in Afghanistan", The International Journal of Human Resource Management, doi

http://dx.doi.org/10.1080/09585192.2017.1291531, Special Issue on Hostile Environments.

Doherty, N. and Dickmann, M. (2012), "Measuring the return on investment in international assignments: an action research approach", The International Journal of Human Resource Management, Vol 23, No. 16, pp. 3434-3454.

Doherty, N., Dickmann, M. and Mills, T. (2011), "Exploring the motives of company-backed and self-initiated expatriates", The International Journal of Human Resource Management, Vol. 22 No. 3, pp. 595-611.

Doherty, N., Richardson, J. and Thorn, K. (2013), "Self-initiated expatriation and selfinitiated expatriates: clarification of the research stream", Career Development International, Vol. 18 No. 1, pp. 97-112.

Dowling, P.J., Festing, M. and Engle, A. (2013), International Human Resource Management, 6th edn., Cengage Learning, London.

Downes, M., Varner, I.I. and Hemmasi, M. (2010), "Individual profiles as predictors of expatriate effectiveness", Competitiveness Review: An International Business Journal, Vol. 20 No. 3, pp. 235-247.

Dupuis, M.J., Haines III, V.Y. and Saba, T. (2008), "Gender, family ties, and international mobility: cultural distance matters", The International Journal of Human Resource Management, Vol. 19 No. 2, p. 274-295.

Emigh, R. (1997), "The power of negative thinking: the use of negative case methodology in the development of sociological theory", Theory and Society, Vol. 26 No. 5, pp. 649-684.

Fisher, C. (2010), “Collecting and Analyzing Research Material”, in Fisher, C., Buglear, J., Lowry, D., Mutch, A. and Tansley, C. (eds.) Researching and writing a Dissertation: An Essential Guide for Business Students, 3rd edn. Prentice Hall, London, pp. 167-241. 
Fisher, K. and Hutchings, K. (2013), "Making sense of cultural distance for military expatriates operating in an extreme context", Journal of Organizational Behavior, Vol. 34 No. 6, pp. 791-812.

Fisher, K., Hutchings, K. and Pinto, L.H. (2015), "Pioneers across war zones: the lived acculturation experiences of US female military expatriates", International Journal of Intercultural Relations, Vol. 49, Nov, pp. 265-277.

Froese, F.J., Jommersbach, S. and Klautzsch, E. (2013), “Cosmopolitan career choices: a cross-cultural study of job candidates' expatriation willingness", The International Journal of Human Resource Management, Vol. 24 No. 17, pp. 3247-3261.

Giustozzi, A. (2008), Koran, Kalashnikov, and Laptop: The Neo-Taliban Insurgency in Afghanistan, Columbia University Press, New York.

Gonzalez, R. and Negandhi, A. (1967), The United States Overseas Executive: His Orientations and Career Patterns, Institute for International Business and Economic Development Studies, Division of Research, Graduate School of Business Administration, Michigan State University, Michigan.

Harvey, M. (1997), "Dual-career expatriates: expectations, adjustment and satisfaction with international relocation", Journal of International Business Studies, Vol. 28 No. 3, pp. 627658.

Harvey, M. (1985), “The executive family: an overlooked variable in international assignments", Thunderbird International Business Review, Vol. 27 No. 3, pp. 15-16.

Harvey, M. (1997), "Dual-career expatriates: expectations, adjustment and satisfaction with international relocation”, Journal of International Business Studies, Vol. 28 No. 3, pp. 627658.

Haslberger, A., Brewster, C. and Hippler, T. (2013), "The dimensions of expatriate adjustment”, Human Resource Management, Vol. 52 No. 3, pp. 333-351.

Haslberger, A., Brewster, C. and Hippler, T. (2014), Managing Performance Abroad: A New Model for Understanding Expatriate Adjustment. Routledge, Abingdon, Oxon.

Haslberger, A. and Dickmann, M. (2016), "The correspondence model of cross-cultural adjustment: exploring exchange relationships", Journal of Global Mobility: The Home of Expatriate Management Research, Vol. 4 No. 3, pp. 276-299.

Harris, H., Brewster, C., and Sparrow, P. (2003), International human resource management. CIPD Publishing, London.

Hippler, T. (2009), "Why do they go? Empirical evidence of employees' motives for seeking or accepting relocation", International Journal of Human Resource Management, Vol. 20 No. 6, pp. 1381-1401. 
Hippler, T., Brewster, C. and Haslberger, A. (2015), "The elephant in the room: the role of time in expatriate adjustment", The International Journal of Human Resource Management, Vol. 26 No. 15, pp. 1920-1935.

Hurn, B.J. (1999), "Repatriation-the toughest assignment of all”, Industrial and Commercial Training, Vol. 31 No. 6, pp. 224-228.

Inkson, K. and Arthur, M.B. (2001), "How to be a successful career capitalist", Organizational Dynamics, Vol. 30 No. 1, pp. 48-61.

Inkson, K. and Myers, B.A. (2003), “'The big OE': self-directed travel and career development”, Career Development International, Vol. 8 No. 4, pp. 170-181.

Jokinen, T. (2010), "Development of career capital through international assignments and its transferability to new contexts", Thunderbird International Business Review, Vol. 52 No. 4, pp. 325-337.

Jokinen, T., Brewster, C. and Suutari, V. (2008), "Career capital during international work experiences: contrasting self-initiated expatriate experiences and assigned expatriation", The International Journal of Human Resource Management, Vol. 19 No. 6, pp. 979-998.

Jones, S. (2000), "Medical aspects of expatriate health: health threats", Occupational Medicine, Vol. 50 No. 8, pp. 572-578.

Kim, J. and Froese, F.J. (2012), "Expatriation willingness in Asia: the importance of hostcountry characteristics and employees' role commitments", The International Journal of Human Resource Management, Vol. 23 No. 16, pp. 3414-3433.

Lamb, M. and Sutherland, M. (2010), "The components of career capital for knowledge workers in the global economy", International Journal of Human Resource Management, Vol. 21 No. 3, pp. 295-312. doi:10.1080/09585190903546839.

Mäkelä, K., Björkman, I. and Ehrnrooth, M.,(2009), MNC subsidiary staffing architecture: building human and social capital within the organisation. The International Journal of Human Resource Management, Vol 20, No 6, pp.1273-1290.

Mäkelä, L., Suutari, V., Brewster, C., Dickmann, M. and Tornikoski, C. (2016), "The impact of career capital on expatriates' perceived marketability", Thunderbird International Business Review, Vol. 58 No. 1, pp. 29-40.

Morley, M. and Heraty, M. (2004), "International assignments and global careers", Thunderbird International Business Review, Vol. 46 No. 6, pp. 633-646.

Murtazashvili, J.B. (2016), Informal Order and the State in Afghanistan. Cambridge University Press, New York.

Oberholster, A.J., Clarke, R., Bendixen, M. and Dastoor, B. (2013), "Expatriate motivation in religious and humanitarian non-profit-organizations", Journal of Global Mobility, Vol. 1 No. 1, pp. 7-27. 
Oh, C.H. and Oetzel, J. (2011), "Multinationals' response to major disasters: how does subsidiary investment vary in response to the type of disaster and the quality of country governance?” Strategic Management Journal, Vol. 32 No. 6, pp. 658-681.

Ott, D.L. and Michailova, S. (2016), "Cultural intelligence: A review and new research avenues", International Journal of Management Reviews, doi:10.1111/ijmr.12118

Parker, P., Khapova, S. and Arthur, M. (2009), "The intelligent career framework as a basis for interdisciplinary inquiry”, Journal of Vocational Behavior, Vol. 75 No. 3, pp. 291-302.

Pattie, M.W., Benson, G., Casper, W. and McMahan, G.C. (2013), "Goal congruence: fitting international assignment into employee careers", The International Journal of Human Resource Management, Vol. 24 No. 13, pp. 2554-2570.

Pattie, M., White, M.M. and Tansky, J. (2010), "The homecoming: a review of support practices for repatriates”, Career Development International, Vol. 15 No. 4, pp. 359-377.

Piekkari, R., Welch, C. and Paavilainen, E. (2009), "The case study as disciplinary convention: evidence from international business journals", Organizational Research Methods Vol. 12 No. 3, pp. 567-589.

Pinto, L.H. and Caldas, R. (2015), "Making sense of expatriation", Management Research: The Journal of the Iberoamerican Academy of Management, Vol. 13 No. 3, pp. 267-284.

Pinto, L.H., Cabral-Cardoso, C. and Werther Jr, W.B. (2012), "Compelled to go abroad? Motives and outcomes of international assignments", The International Journal of Human Resource Management, Vol. 23 No. 11, pp. 2295-2314.

Remhof, S., Gunkel, M. and Schlaegel, C. (2014), "Goodbye Germany! The influence of personality and cognitive factors on the intention to work abroad", The International Journal of Human Resource Management, Vol. 25 No. 16, pp. 2319-2343.

Riusala, K. and Suutari, V. (2000), "Expatriation and careers: perspectives of expatriates and spouses", Career Development International, Vol. 5 No. 2, pp. 81-90.

Schoepp, K. and Forstenlechner, I. (2010), "The role of family considerations in an expatriate majority environment", Team Performance Management: An International Journal, Vol. 16 No. 5/6, pp. 309-323.

Shaffer, M.A., Kraimer, M.L., Chen, Y-P. and Bolino, M.C. (2012), "Choices, challenges, and career consequences of global work experiences: a review and future agenda", The Journal of Management, Vol. 38 No. 4, pp. 1282-1327.

Stahl, G.K., and Caligiuri, P. (2005), "The effectiveness of expatriate coping strategies: the moderating role of cultural distance, position level, and time on the international assignment", Journal of Applied Psychology, Vol. 90 No. 4, pp. 603-615.

Stahl, G.K. and Cerdin, J-L. (2004), "Global careers and French and German multinational corporations", Journal of Management Development, Vol. 23 No. 9, pp. 885-902. 
Stahl, G.K., Chua, C.H., Caligiuri, P., Cerdin, J. and Taniguchi, M. (2009), "Predictors of turnover intentions in learning-driven and demand-driven international assignments: the role of repatriation concerns, satisfaction with company support, and perceived career advancement opportunities", Human Resource Management, Vol. 48 No. 1, pp. 89-109.

Stahl, G.K., Miller, E.L. and Tung, R.L. (2002), "Towards the boundaryless career: a closer look to the expatriate career concept and the perceived implications of an international assignment", Journal of World Business, Vol. 37, pp. 216-227.

Street, A.E., Gradus, J.L., Giasson, H.L., Vogt, D. and Resick, P.A. (2013), “Gender differences among veterans deployed in support of the wars in Afghanistan and Iraq", Journal of General Internal Medicine, Vol. 28 No. 2, pp. 556-562.

Sullivan, S.E. (1999), "The changing nature of careers: a review and research agenda", Journal of Management, Vol. 25 No. 3, pp. 457-484.

Suutari, V., Brewster, C., Mäkelä, L., Dickmann, M. and Tornikoski, C. (2017), “The effect of international work experience on the career success of expatriates: a comparison of assigned and self-initiated expatriates", Human Resource Management, doi: $10.1002 / \mathrm{hrm} .21827$.

Takeuchi, R. (2010), “A critical review of expatriate adjustment research through a multiple stakeholder view: progress, emerging trends and prospects", Journal of Management, Vol. 36 No. 4, pp. 1040-1064.

The RES Forum Annual Report (2016), "Beyond uniformity - a world of opportunity", Report authored by Michael Dickmann, The RES Forum, Harmony Relocation Network and Equus Software, 116 pages, London.

Thomas, D.C. and Inkson, K. C. (2009), Cultural Intelligence: Living and Working Globally. Berrett-Koehler, California.

Vance, C.M. and McNulty, Y. (2014), "Why and how women and men acquire global career experience: a study of American expatriates in Europe", International Studies of Management and Organization, Vol. 44 No. 2, pp. 34-54.

Van Emmerik, I.J.H. and Euwema, M.C. (2009), "The international assignments of peacekeepers: what drives them to seek future expatriation?" Human Resource Management, Vol. 48 No. 1, pp. 135-151.

Yurkiewicz, J. and Rosen, B. (1995), "Increasing receptivity to expatriate assignments", in Selmer J. (ed.) Expatriate Management, Quorum, Westport, CT, pp. 37-56. 


\section{Appendix 1. Interview Protocol}

Thank the interviewee for agreeing to take part in this interview.

Confirm details of: Surname, Forename, Date of Birth, Gender, Nationality, age, work location, Job Title, Grade, type of contract, personal circumstances, languages spoken and level of education.

1. Are they currently on International assignment, if so, where?

2. Have they done international assignments in fragile states or conflict environments such as Afghanistan or Pakistan in the past, if so, where, when and the type of post?

3. If they have ask the following, if not go to question 4.
a. Why did you take up these IAs?
b. What were your personal circumstances at the time (e.g. single)?
c. What did you learn from your IA?
d. What benefit did you get from the IA?
e. How did they compare to your expectations?
f. Would you take up an IA in a fragile environment again?
g. How do you think this experience differ from going to a non-fragile environment?
h. What knowledge, skills and abilities did you build up whilst overseas in fragile environment?
i. How did this help your career?
j. How is this different from the assignment you took up in a non-fragile environment?
k. What networks did you build up whilst overseas in fragile states and did this help your career?
1. How did this build your motivation to work within [organization] / how did this build up your motivation to work within fragile states?
m. What affect did the IA have on your career?
n. How do you think it would affect your career if you had gone to non-fragile states and your home location?

4. If you have not previously taken up such an assignment why not?

5. Would you be interested in taking up an assignment in future in a fragile environment?

6. What would increase your interest in taking up another assignment in future in a Fragile / Conflict State?

7. How could [Organization] support you more to take up an IA in a Fragile / Conflict State?

8. How have you developed your career and what do you expect this to look like within [organization]?

9. If you took up an IA in a fragile environment where would this fit within your career within [organization]?

10. Is there anything I have not asked about that affected your decision to take up an IA in a Fragile or Conflict State?

11. Why did you join [organization]?

12. Why do you work for [organization] now?

13. Any questions before we conclude?

Thank you for being involved in this study. 
Table 1. Overview of Interviewees

\begin{tabular}{cccccccc}
\hline No & $\begin{array}{c}\text { Work in } \\
\text { HE? }\end{array}$ & $\begin{array}{c}\text { Specialist/ } \\
\text { Generalist }\end{array}$ & $\begin{array}{c}\text { Se } \\
\text { X }\end{array}$ & Marital Status & National & $\begin{array}{c}\text { No of } \\
\text { Chil }\end{array}$ & $\begin{array}{c}\text { No of HE } \\
\text { IAs }\end{array}$ \\
\hline 1 & No & Specialist & M & Married & British & $1-3$ & 0 \\
2 & No & Specialist & M & Married & British & $1-3$ & 1 \\
3 & No & Generalist & M & Relationship & British & 0 & 2 \\
4 & No & Specialist & F & Single & British & 0 & 0 \\
5 & No & Generalist & M & Civil Partnership & British & $1-3$ & 2 \\
6 & No & Generalist & M & Relationship & British & 0 & 0 \\
7 & No & Specialist & F & Single & British & 0 & 1 \\
8 & No & Specialist & F & Single & British & 0 & 5 \\
9 & No & Generalist & F & Relationship & British & 0 & 3 \\
10 & Yes & Specialist & F & Divorced & British & $1-3$ & 0 \\
11 & Yes & Generalist & F & Married & Canada & $1-3$ & 0 \\
12 & Yes & Specialist & F & Married & Canada & $1-3$ & 1 \\
13 & Yes & Generalist & F & In a relationship & British & $1-3$ & 3 \\
14 & Yes & Generalist & M & Married & British & $3+$ & 2 \\
15 & Yes & Specialist & F & Married & British & 0 & 2 \\
16 & Yes & Specialist & M & Civil Partnership & British & 0 & 2 \\
17 & Yes & Generalist & M & Civil Partnership & British & 0 & 1 \\
18 & Yes & Generalist & F & Single & British & 0 & 2 \\
19 & Yes & Specialist & F & Married & Canada & 0 & 0 \\
20 & Yes* & Generalist & F & Married & British & $1-3$ & 1 \\
21 & Yes* & Generalist & F & Married & British & $1-3$ & 5 \\
22 & Yes* & Generalist & M & Married & British & $1-3$ & 5 \\
23 & Yes* & Generalist & M & Married & British & 0 & 1 \\
24 & Yes* & Generalist & F & Single & British & 0 & 1 \\
25 & Yes* & Generalist & F & Single & British & 0 & 3 \\
\hline Yes* refers to when an individual is currently working in a conflict location. $^{*}$ & & & \\
& & & & & & &
\end{tabular}


Table 2. Data Hierarchy
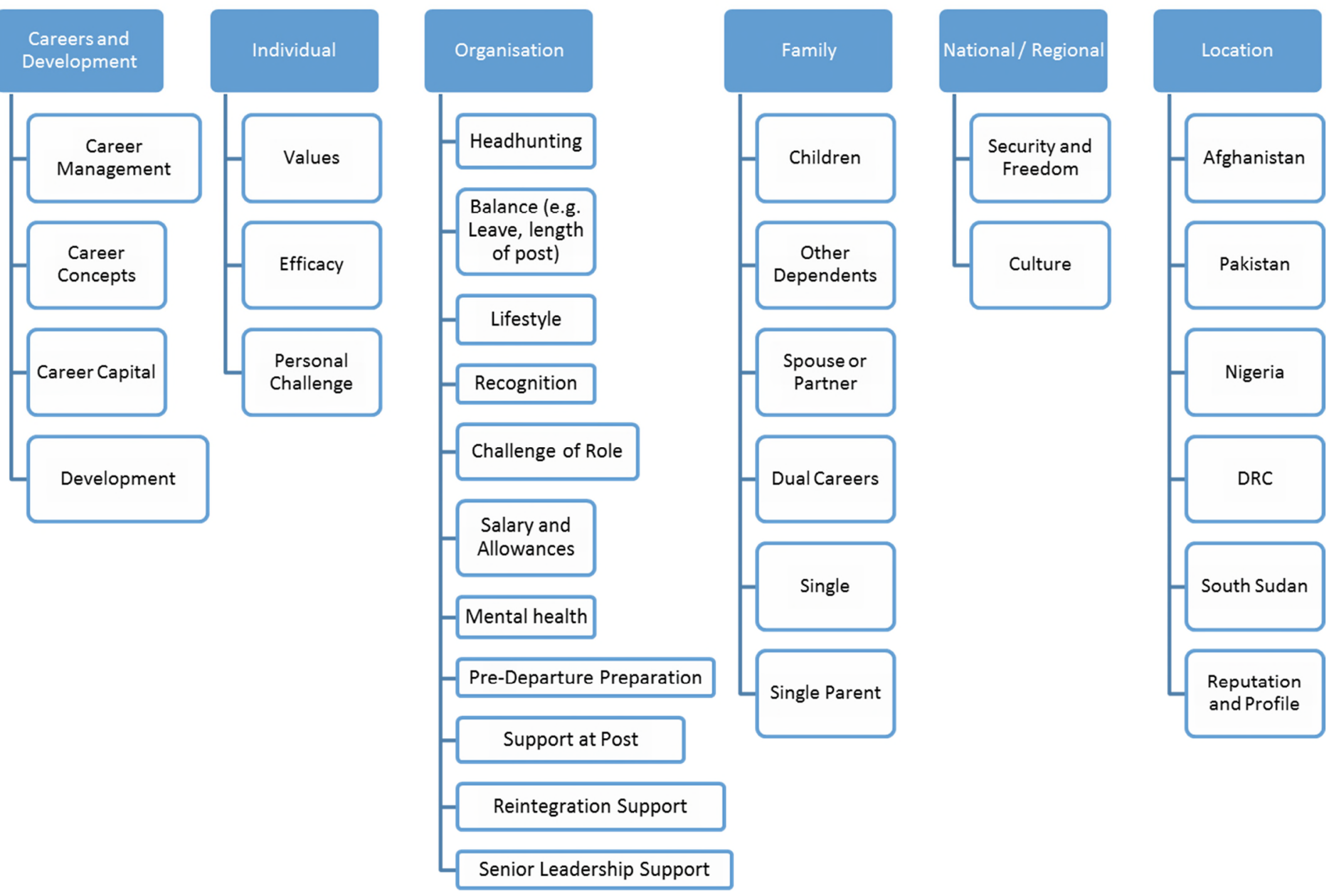

Data hierarchy based on Dickmann (2012). 
Table 3. Drivers of HEs and the Impact of this Research on the Literature

\begin{tabular}{|c|c|c|}
\hline Study Findings & Earlier Research & Contributions \\
\hline \multicolumn{3}{|c|}{ Individual Factors - Professional Interests } \\
\hline $\begin{array}{l}\text { This is the case in HEs as well as other } \\
\text { environments. }\end{array}$ & $\begin{array}{l}\text { Inkson and Arthur (2001); Shaeffer et al. (2012), Suutari et } \\
\text { al. (2017) } \\
\text { Career capital, knowing how, why and who framework is } \\
\text { sought by individuals } \\
\text { Individuals seek to strengthen their internal and external } \\
\text { marketability }\end{array}$ & Supported \\
\hline $\begin{array}{l}\text { Supported, in addition to this career } \\
\text { capital may be differentiated between } \\
\text { the parent and the subsidiary } \\
\text { organisation, with certain assignments } \\
\text { perceived to be less valuable within the } \\
\text { department but of value across } \\
\text { government. }\end{array}$ & $\begin{array}{l}\text { Jokinen et al., (2008); Jokinen (2010); Dickmann et al., } \\
2016, \text { Suutari et al., } 2017 \\
\text { Individuals build career capital to make themselves } \\
\text { attractive to future employers. } \\
\text { Career capital built on IAs is different and transferrable in } \\
\text { different ways. } \\
\text { Marketability has increased }\end{array}$ & $\begin{array}{l}\text { Supported and } \\
\text { Expanded }\end{array}$ \\
\hline \multicolumn{3}{|c|}{ Individual Factors - Personal Drivers and Interests } \\
\hline This was confirmed. & $\begin{array}{l}\text { Dickmann et al. (2008); Hippler (2009); Oberholster et al. } \\
\text { (2013) } \\
\text { Individuals have a large range of personal drivers and } \\
\text { interests, including seeking adventure, exploration and self- } \\
\text { fulfilment }\end{array}$ & Supported \\
\hline \multicolumn{3}{|c|}{ Individual Factors - Personal Dispositions } \\
\hline $\begin{array}{l}\text { In HEs there is the added issue of } \\
\text { mental health and coping with } \\
\text { traumatic events e.g. PTSD. }\end{array}$ & $\begin{array}{l}\text { Caligiuri (2012), Takeuchi (2010) } \\
\text { Psychological factors and cultural agility impact } \\
\text { expatriation success and willingness to work abroad } \\
\text { Stressors impact on expatriate adjustment and re- } \\
\text { integration }\end{array}$ & $\begin{array}{l}\text { Supported and } \\
\text { Expanded }\end{array}$ \\
\hline \multicolumn{3}{|c|}{ Individual Factors - Family and Partner } \\
\hline $\begin{array}{l}\text { Dual Career considerations have an } \\
\text { impact on accepting IAs. }\end{array}$ & $\begin{array}{l}\text { Harvey, (1997); Vance \& McNulty (2014) } \\
\text { Individuals considered their partner's work and career } \\
\text { implications when deciding to work in an HE. }\end{array}$ & Supported \\
\hline $\begin{array}{l}\text { Family influences can be positive as } \\
\text { well as negative. }\end{array}$ & $\begin{array}{l}\text { Harvey (1985), Richardson and Mallon (2005), Kim \& } \\
\text { Froese (2012) } \\
\text { Individuals returned to country of origin due to their family } \\
\text { commitments, especially for the education available. }\end{array}$ & Supported \\
\hline \multicolumn{3}{|c|}{ Organizational Factors - Financial Benefits (Expatriate Package) } \\
\hline $\begin{array}{l}\text { For organisational influencers financial } \\
\text { rewards and other expatriate package } \\
\text { elements are the important concerns. }\end{array}$ & $\begin{array}{l}\text { Stahl et al., (2002), Dickmann et al., (2008) } \\
\text { Financial package important for individuals. } \\
\text { As long as the financial package is fair for individuals the } \\
\text { benefit elements of the organisation package such as } \\
\text { leave, length of IA, travel is more of a priority to individuals. } \\
\text { This is because they enable contact with family and / or } \\
\text { pursue travel / social activities. }\end{array}$ & $\begin{array}{l}\text { Financial } \\
\text { Supported } \\
\text { Benefits } \\
\text { considerations } \\
\text { expanded }\end{array}$ \\
\hline \multicolumn{3}{|c|}{ Organizational Factors: Non-Financial (Job Characteristics, Support Practices) } \\
\hline $\begin{array}{l}\text { Dissatisfaction with past re-integration } \\
\text { support or what they have heard from } \\
\text { their colleagues on this subject } \\
\text { influenced individuals not to take up an } \\
\text { IA. }\end{array}$ & $\begin{array}{l}\text { Pattie et al (2010) } \\
\text { Support practices, including a focus on Reintegration } \\
\text { support reduce expatriate turnover. }\end{array}$ & Supported \\
\hline \multicolumn{3}{|c|}{ Location Factors - National Considerations } \\
\hline National influences were supported. & $\begin{array}{l}\text { Kim and Froese (2012); De Eccher \& Duarte (2016) } \\
\text { National characteristics - including climate, language, host } \\
\text { country population - important for decision to go }\end{array}$ & Supported \\
\hline \multicolumn{3}{|c|}{ Location Factors- Specific City or Rural Considerations } \\
\hline $\begin{array}{l}\text { For HE, security concerns of specific } \\
\text { locations (not simply country) are } \\
\text { highly important } \\
\text { Trust in line manager is paramount to } \\
\text { accept assignment as this could mean } \\
\text { the difference between life and death. }\end{array}$ & $\begin{array}{l}\text { Dickmann \& Mills (2010), Dickmann (2012), de Eccher \& } \\
\text { Duarte (2016) } \\
\text { The expansion of research to include location specific } \\
\text { factors as an additional category. }\end{array}$ & $\begin{array}{l}\text { Supported and } \\
\text { Expanded }\end{array}$ \\
\hline
\end{tabular}


Table 3. Career and Promotion Patterns in the Case Organization

\begin{tabular}{|l|c|c|c|c|c|c|c|}
\hline & Afghan & Pakistan & Nigeria & Sudan & $\begin{array}{c}\text { South } \\
\text { Sudan }\end{array}$ & DRC & Total \\
\hline Total No of Staff & 44 & 20 & 33 & 13 & 19 & 25 & 154 \\
\hline Total No of Staff Promoted on Starting in Country & 1 & 0 & 0 & 2 & 2 & 4 & 9 \\
\hline Total No of Staff Promoted in Country & 5 & 4 & 0 & 2 & 1 & 6 & 18 \\
\hline Total No of Staff Promoted Leaving Country & 10 & 3 & - & - & - & - & 13 \\
\hline Total Promotions & $\mathbf{1 6}$ & $\mathbf{7}$ & $\mathbf{0}$ & $\mathbf{4}$ & $\mathbf{3}$ & $\mathbf{6}$ & 36 \\
\hline Total No of People Promoted & $\mathbf{1 5}$ & $\mathbf{7}$ & $\mathbf{0}$ & $\mathbf{4}$ & $\mathbf{3}$ & $\mathbf{6}$ & 35 \\
\hline$\%$ of People Promoted & $\mathbf{3 4 \%}$ & $\mathbf{3 5 \%}$ & - & $\mathbf{3 1 \%}$ & $\mathbf{1 6 \%}$ & $\mathbf{4 0 \%}$ & $\mathbf{2 2 . 7 3 \%}$ \\
\hline
\end{tabular}

(based on organizational data) 
Table 4. Drivers of HEs and the Impact of this Research on the Literature

\begin{tabular}{|c|c|c|c|}
\hline $\begin{array}{l}\text { Selected } \\
\text { Literature }\end{array}$ & Authors' Findings & Our Research Findings & Status \\
\hline \multicolumn{4}{|c|}{ Individual Factors - Professional Interests } \\
\hline $\begin{array}{l}\text { Inkson and Arthur } \\
\text { (2001); Shaeffer } \\
\text { et al. (2012), } \\
\text { Suutari et al. } \\
\text { (2017) }\end{array}$ & $\begin{array}{l}\text { Career capital, knowing how, why and } \\
\text { who framework is sought by } \\
\text { individuals } \\
\text { Individuals seek to strengthen their } \\
\text { internal and external marketability }\end{array}$ & $\begin{array}{l}\text { This is the case in HEs as well as other } \\
\text { environments. }\end{array}$ & Supported \\
\hline $\begin{array}{l}\text { Jokinen et al., } \\
\text { (2008); } \\
\text { Jokinen (2010); } \\
\text { Dickmann et al., } \\
2016 \\
\text { Suutari et al., } \\
2017 \\
\end{array}$ & $\begin{array}{l}\text { Individuals build career capital to make } \\
\text { themselves attractive to future } \\
\text { employers. } \\
\text { Career capital built on IAs is different } \\
\text { and transferrable in different ways. } \\
\text { Marketability has increased }\end{array}$ & $\begin{array}{l}\text { Supported, in addition to this career capital } \\
\text { may be differentiated between the parent } \\
\text { and the subsidiary organisation, with } \\
\text { certain assignments perceived to be less } \\
\text { valuable within the department but of value } \\
\text { across government. }\end{array}$ & $\begin{array}{l}\text { Supported } \\
\text { and expanded }\end{array}$ \\
\hline \multicolumn{4}{|c|}{ Individual Factors - Personal Drivers and Interests } \\
\hline $\begin{array}{l}\text { Dickmann et al. } \\
\text { (2008); Hippler } \\
\text { (2009); } \\
\text { Oberholster et al. } \\
\text { (2013) }\end{array}$ & $\begin{array}{l}\text { Individuals have a large range of } \\
\text { personal drivers and interests, } \\
\text { including seeking adventure, } \\
\text { exploration and self-fulfilment }\end{array}$ & $\begin{array}{l}\text { Confirmed, in addition political views may } \\
\text { deter individuals to take up an IA in HEs }\end{array}$ & $\begin{array}{l}\text { Supported } \\
\text { and expanded }\end{array}$ \\
\hline \multicolumn{4}{|c|}{ Individual Factors - Personal Dispositions } \\
\hline $\begin{array}{l}\text { Caligiuri (2012) } \\
\text { Takeuchi (2010) }\end{array}$ & $\begin{array}{l}\text { Psychological factors and cultural } \\
\text { agility impact expatriation success and } \\
\text { willingness to work abroad } \\
\text { Stressors impact on expatriate } \\
\text { adjustment and re-integration }\end{array}$ & $\begin{array}{l}\text { In HEs there is the added issue of mental } \\
\text { health and coping with traumatic events } \\
\text { e.g. PTSD. }\end{array}$ & $\begin{array}{l}\text { Supported } \\
\text { and } \\
\text { Expanded }\end{array}$ \\
\hline \multicolumn{4}{|c|}{ Individual Factors - Family \& Partner } \\
\hline $\begin{array}{l}\text { Harvey, (1997); } \\
\text { Vance \& McNulty } \\
\text { (2014) }\end{array}$ & $\begin{array}{l}\text { Dual Career considerations have an } \\
\text { impact on accepting IAs. }\end{array}$ & $\begin{array}{l}\text { Individuals considered their partner's work } \\
\text { and career implications when deciding to } \\
\text { work in an HE. }\end{array}$ & Supported \\
\hline $\begin{array}{l}\text { Harvey (1985) } \\
\text { Richardson and } \\
\text { Mallon (2005) } \\
\text { Kim \& Froese } \\
\text { (2012) }\end{array}$ & $\begin{array}{l}\text { Family influences can be positive as } \\
\text { well as negative. }\end{array}$ & $\begin{array}{l}\text { Individuals returned to country of origin due } \\
\text { to their family commitments, especially for } \\
\text { the education available. }\end{array}$ & Supported \\
\hline \multicolumn{4}{|c|}{ Organisational Factors - Financial and Benefits (Expatriate Package) } \\
\hline $\begin{array}{l}\text { Stahl et al., } \\
(2002) \\
\text { Dickmann et al., } \\
(2008)\end{array}$ & $\begin{array}{l}\text { For organisational influencers financial } \\
\text { rewards and other expatriate package } \\
\text { elements are the important concerns. }\end{array}$ & $\begin{array}{l}\text { Financial package important for individuals. } \\
\text { As long as the financial package is fair for } \\
\text { individuals the benefit elements of the } \\
\text { organisation package such as leave, length } \\
\text { of IA, travel is more of a priority to } \\
\text { individuals. This is because they enable } \\
\text { contact with family and / or pursue travel / } \\
\text { social activities. }\end{array}$ & $\begin{array}{l}\text { Financial } \\
\text { Supported } \\
\text { Benefits } \\
\text { considerations } \\
\text { expanded }\end{array}$ \\
\hline \multicolumn{4}{|c|}{ Organizational Factors: Non-Financial (Job Characteristics, Support Practices) } \\
\hline Pattie et al (2010) & $\begin{array}{l}\text { Support practices, including a focus on } \\
\text { Reintegration support reduce } \\
\text { expatriate turnover. }\end{array}$ & $\begin{array}{l}\text { Dissatisfaction with past re-integration } \\
\text { support or what they have heard from their } \\
\text { colleagues on this subject influenced } \\
\text { individuals not to take up an IA. }\end{array}$ & Supported \\
\hline \multicolumn{4}{|c|}{ Location Factors - National Considerations } \\
\hline $\begin{array}{l}\text { Kim and Froese } \\
\text { (2012); } \\
\text { De Eccher \& } \\
\text { Duarte }(2016)\end{array}$ & $\begin{array}{l}\text { National characteristics - including } \\
\text { climate, language, host country } \\
\text { population - important for decision to } \\
\text { go }\end{array}$ & National influences were supported. & Supported \\
\hline \multicolumn{4}{|c|}{ Location Factors- Specific City or Rural Considerations } \\
\hline $\begin{array}{l}\text { Dickmann \& Mills } \\
\text { (2010), } \\
\text { Dickmann (2012) } \\
\text { de Eccher \& } \\
\text { Duarte (2016) }\end{array}$ & $\begin{array}{l}\text { The expansion of research to include } \\
\text { location specific factors as an } \\
\text { additional category. }\end{array}$ & $\begin{array}{l}\text { For HE, security concerns of specific } \\
\text { locations (not simply country) are highly } \\
\text { important } \\
\text { Trust in line manager is paramount to } \\
\text { accept assignment as this could mean the } \\
\text { difference between life and death }\end{array}$ & $\begin{array}{l}\text { Supported } \\
\text { and } \\
\text { Expanded }\end{array}$ \\
\hline
\end{tabular}


2017-09-30

\title{
pÿ I might be shot at! exploring the
} drivers to work in hostile environments using an intelligent careers perspective

\author{
Dickmann, Michael
}

Emerald

pÿMichael Dickmann and Ashley Helen Watson, (2017) I might be shot at! exploring the drivers to work in hostile environments using an intelligent careers perspective", Journal of Global Mobility: The Home of Expatriate Management Research, Vol. 5 Issue: 4, pp.348-373 https://doi.org/10.1108/JGM-12-2016-0066

Downloaded from Cranfield Library Services E-Repository 